\title{
New insights into the ancient silver production of the Wallis area, Switzerland
}

\author{
Barbara Guénette-Beck • Nicolas Meisser • \\ Philippe Curdy
}

Received: 7 April 2009 /Accepted: 4 August 2009/Published online: 9 September 2009

(C) Springer-Verlag 2009

\begin{abstract}
This paper discusses the results of a study of the exploitation history of the metallogenic region of the Wallis, Switzerland. Periods of exploitation in this mining district are determined by comparisons of the lead isotope fingerprint of the mines with those of dated artefacts presumed to have a local origin based on the style of craftsmanship. The approach is based on the study of silver mines in the Wallis area and illustrated by three examples of local craftsmanship: (1) silver jewellery from the Late Iron Age, (2) a reliquary shrine from the Early Middle Ages and (3) silver coins from the Late Middle Age.
\end{abstract}

Keywords Lead isotopes · Metallogenic region .

Silver trade $\cdot$ Late Iron Age $\cdot$ Middle ages

\section{Introduction}

The study of lead isotopes is a widely applied method for determining the origin of an archaeological artefact, by comparing its isotopic composition to that of different ores.

\footnotetext{
B. Guénette-Beck $(\bowtie)$

Department of Geosciences, University of Fribourg,

Fribourg, Switzerland

e-mail: barbara.guenette-beck@unifr.ch

N. Meisser

Geological Museum,

Lausanne, Switzerland

e-mail: nicolas.meisser@unil.ch

P. Curdy

Museum of History,

Sion, Switzerland

e-mail: philippe.curdy@admin.vs.ch
}

The results of these studies are often unsatisfactory because the origin of a specific artefact cannot always be unequivocally proven. The lead isotopic signature of ore from a given mine is not unique and values may overlap with those of mines from other areas. Further problems arise on account of the quality of the databases on ore composition: Frequently, there is no information concerning the nature of the mineralisation (poly-metallic, lead, silver, copper ore etc.) and the complexity of the ore body (number and relationships between the mineralisation events). Furthermore, the number of analyses per mineralisation is often insufficient. Therefore, it is sometimes difficult to indisputably identify a source mine or area.

Another approach, although based on lead isotope analyses, is to study the history of production in a metallogenic region and to determine its importance regarding trade. This paper focuses on this second approach. At first, the lead and silver mining resources of the Wallis area are discussed, and subsequently, an overview of the mining activities in the past is provided. The study is illustrated by the results from specific case studies conducted during a Ph.D. thesis (Guénette-Beck 2005) on the lead and silver production in the Wallis area from the Iron Age to the Medieval Period.

\section{The silver mining district of the Wallis area (Switzerland)}

The studied region corresponds to the Wallis Mountains of Switzerland (Fig. 1). They form a geographical entity, easily accessible not only from the west by the Rhone valley but also from other directions by the high Alpine passes. This region can be considered as one of the most important mining districts in Switzerland. Traces of 
Fig. 1 Map of the studied area. The red circles indicate the localities of the silver artefacts discussed in the three examples; these are 1 the jewellery from Randogne-Bluche, 2 the reliquary shrine from the Abbey of Saint Maurice and 3 the silver coins minted by the bishop of Sion

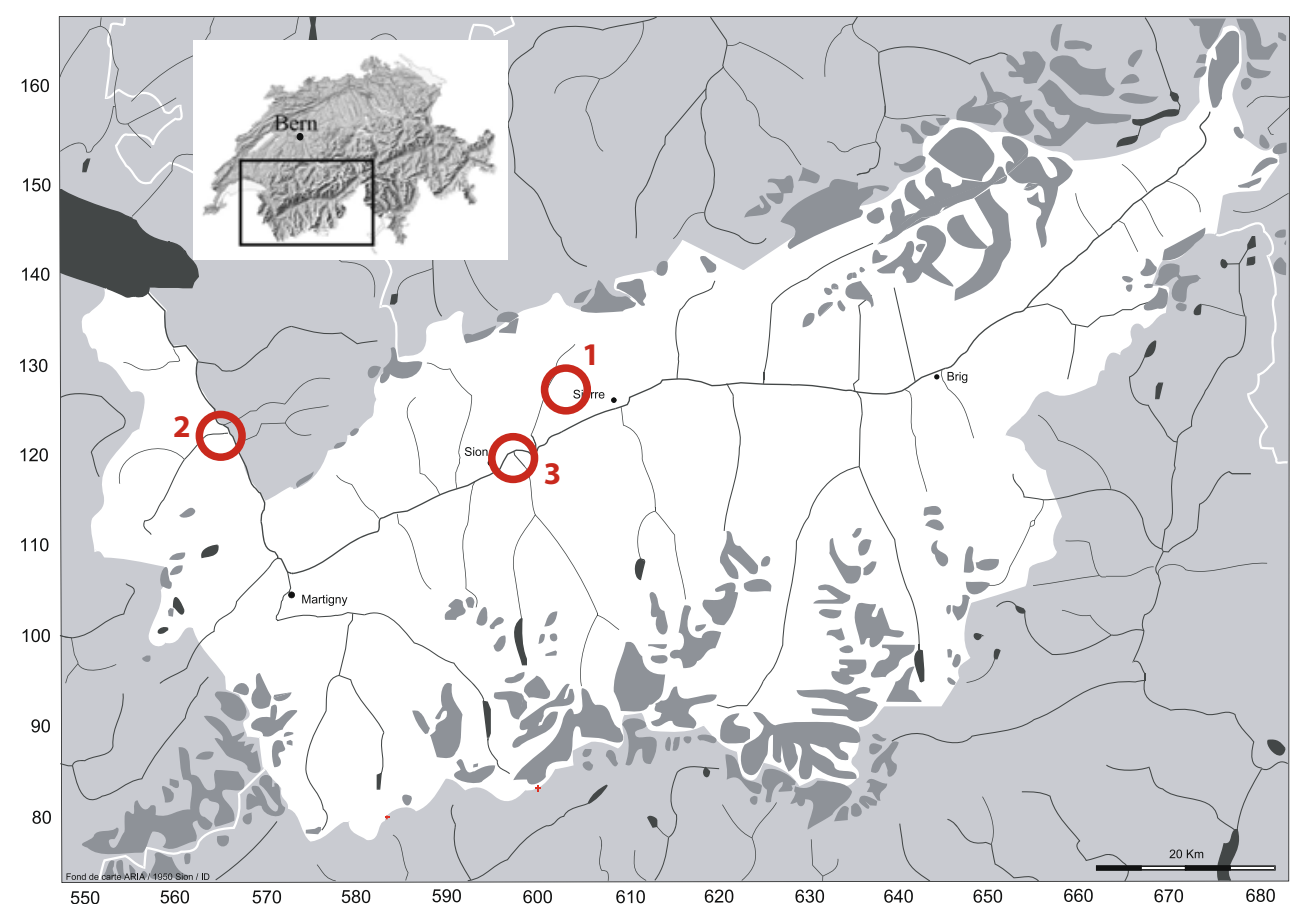

prospecting and mining are characteristic for this landscape and prove a re-current interest for mining exploitation.

Various historical texts comment on the mining activity in the Wallis Mountains since the Middle Ages (GuénetteBeck 2005). The first systematic evaluation of the ore bodies was done, after the conquest of the Wallis, by Napoleon by his mining engineer Geymard, who published his investigation in 1814. Later, other inventories are related to the world wars (Fehlmann 1919; Huttenlocher 1934; Kündig and De Quervain 1941). These inventories are regularly updated (Bugnon 1983 and Woodtli et al 1987). The last inventory was conducted under the supervision of Cavalli et al. (1998).

For earlier periods, we need to base our study on the comparisons of the lead isotope fingerprint of the Wallis mines with those of silver objects to retrace the history of exploitation of the mines. The repeated appearance of a large quantity of silver objects with local typology can indicate the usage of local resources.

The most ancient silver artefacts ${ }^{1}$ excavated in the Wallis area date from the second part of the Iron Age (LT B1-LT D2/AUG: $300 \mathrm{BC}-\mathrm{AD} 15)$. For this period, strong relationships between the people of the Wallis and the Ticino are attested by the types of archaeological findings (earthenware, silver and bronze jewellery) and above all by monetised economy (Haldimann 1998; Curdy 1998). The analysed

\footnotetext{
${ }^{1}$ More than 20 silver jewellery pieces, dating from the LT B1 (300 $\mathrm{BC})$ to the LT D2/AUG (AD 15), have been found in the Wallis area until today. Nine of them dated to the LT D2/AUG. Fifteen of them have been analysed and are published in Guénette-Beck (2005).
}

jewellery shows typology specific for the Wallis area and in the Ticino, which is why local production is suggested by Tori et al. (2009). The local craftsmanship seems to decrease with the arrival of the Romans. In place of this, a wellorganised trade over long distances takes place.

In the Middle Ages, religious silver work $^{2}$ showed an important development in the Wallis (Schweizer and Witschard 2007). One can note the appearance of numerous reliquary chassis, which were exploited to conserve saint's treasures in these reliquary chassis, rather than in the tombs. This was a response to pillages at the time of wars. Numerous tombs were pillaged and precious relics of saints were stolen or destroyed, during the warring expeditions of the Normans, the Vikings and the Hungarians in the ninth and tenth centuries. The conserved relics in the chassis could have been rapidly hidden during these unstable periods (Thurre 1992). These reliquary chassis were manufactured in the Wallis, thus giving reasons to assume that locally produced metal was used.

A third group of objects that could have been crafted in the Wallis were silver coins (Geiser 2004 and Frei-Stolba 1999). In fact, on several occasions, the coins were attributed to the Wallis population. The first minting attributed to the Wallis population is dated at the end of the Iron Age (LT D1: 100-80 BC). From the conquest of the Wallis by the Romans in $15 \mathrm{BC}$, local coin minting ceased, but the minted coins, up until this moment, were still in circulation (Elsig 1993). With the progressive

\footnotetext{
${ }^{2}$ Five reliquaries have been analysed dated from the second part of the twelfth century to the seventeenth century. The data are discussed in Guénette-Beck (2005).
} 
increase of the autonomy of the new kings in the Early Middle Ages, local coin minting took on a new lease of life. The first local minting was accredited to the workshop of Saint Maurice's Abbey from 1000 (Martin 1987). Wallis minting of Episcopal coins peaked at the end of the fifteenth century. Moreover, the last minting dated from $1777 .^{3}$

In this article, the objects of each of these groups (jewellery, religious silver and coins) were chosen in order to retrace by lead isotope sourcing, the most important historical events in the history of mine exploitation in the Wallis: (1) jewellery from Randogne-Bluche which consists of the most ancient silver discovered in the Wallis (LT D2/AUG: $30 \mathrm{BC}$ to $\mathrm{AD} 15$ ), (2) the reliquary chassis of the infants of Saint Sigismund belongs to the most prestigious moment of the utilisation of Wallis silver (twelfth century) and (3) the Episcopal minting belongs to the last local production of Wallis silver (1499-1777).

\section{Analytical method}

The silver artefacts were sampled either by drilling (coins) or by scratching (jewellery and reliquary shrine). Lead isotope analyses were performed at the Laboratory of Isotope Geology at the University of Berne (Prof. I.M. Villa and Prof. J. Kramers). Ore samples, mostly galena, were dissolved in $0.3 \mathrm{M} \mathrm{HNO}_{3}$. The silver samples required a more sophisticated preparation, detailed in Villa (2009). All solutions were spiked by thallium and measured with a $\mathrm{Nu}$ Instruments ${ }^{\mathrm{TM}}$ multi-collector inductively coupled plasma mass spectrometer. Lead isotope ratios were corrected based upon replicate analyses of the NBS SRM 981 lead standard.

\section{Results and discussion}

Evaluation of the mining and lead isotope discrimination potential of the mineralisations in the Wallis area (Switzerland)

Sixty-two localities with lead and silver have been recorded in the Wallis region (Fig. 2). The ores mostly consist of silver-bearing galena containing up to 3 mass $\%$ of silver (Ansermet and Meisser 1997). Sporadically, fahloresessentially tennantite and tetrahedrite-which are complex sulphides of arsenic, antimony, copper, iron, silver and zinc are found. More rarely, silver-rich minerals, with more than

\footnotetext{
${ }_{3}^{3}$ Following analyses have been made (Guénette-Beck 2005): end of the Iron Age: 16 coins from the Wallis and from the region of Lake Geneva and the adjacent area; Early Middle Ages: nine coins circulating in the Wallis; Middle Ages and Late Middle Ages: 16 coins known in the Wallis area.
}

$60 \mathrm{wt.} \%$ of silver (native silver, acanthite, pyrargyrite etc.), are found in the gossan or in the late-stage mineralised veins (Ansermet and Meisser 1996, 1997; Stalder et al. 1998).

The mineralisations of the Wallis area can be attributed to four groups (Guénette-Beck 2005): (1) metamorphic veins, more or less in the form of lenses, depending on the metamorphic degree they experienced; (2) hydrothermal ore bodies; (3) deposits of the Mississippi Valley type and (4) one gossan. The study of the ore bodies of the Wallis area shows that the mineralisation mostly occurs in basement rocks and is associated with metamorphic and magmatic activity. Only four out of 62 localities are related to sedimentary rocks. Field work investigations showed that almost all of these mineralisations are formed by one mineralisation event. There is one unique exception. The mines of Goppenstein are formed by three clearly distinguishable mineralisation events. Based upon field observations, the second mineralisation event is more extensive and important than the two others. This ore body is visible on the surface for over $13 \mathrm{~km}$.

From the 62 localities inventoried, only six ore bodies show an important mining activity for silver and lead, namely the mines of Goppenstein, Praz Jean, Siviez, Col des Mines, Peiloz and Tête de la Payanne (Fig. 2; Table 1). These six ore bodies have common geological features. They are all of hydrothermal origin and underwent at least one metamorphic event. The formation of these ore bodies is related to the complex genesis of the Alps. The mineralisations are linked to major magmatic intrusions of the Caledonian (408 to 387) or Late-Hercynian (333 to 286) orogenies. During these phases of orogeny, tectonic activity opened major fractures and the rocks underwent thermal subsidence, leading to the formation of extended ore deposits. Furthermore, these ore deposits are also derived from important lead reservoirs, such as former clastic rocks rich in urano- and thorogenic lead (Guénette-Beck 2005).

These lead isotopic fingerprints of the Wallis ore bodies are easily distinguished from each other. The mines of Praz Jean, Siviez, Col des Mines, Peiloz and Tête de la Payanne have lead isotopic fingerprints typical for one single mineralisation event, characterised by a linear trend (Fig. 3). This linear trend can be explained by lead derived from the partial fusion of the upper crust; the ore fluid formed in this way is then enriched in lead from the old upper crust by lixiviation during metamorphism, before its deposition (Kramers and Tolstikhin 1997). The ore bodies of the mines of Goppenstein are characterised by a complex lead isotopic fingerprint. The three mineralisation events distinguishable by field work are also distinguishable by lead isotopes. The fingerprint of the main ore body of Goppenstein shows that this mineralisation has been formed by three close sequenced events. 


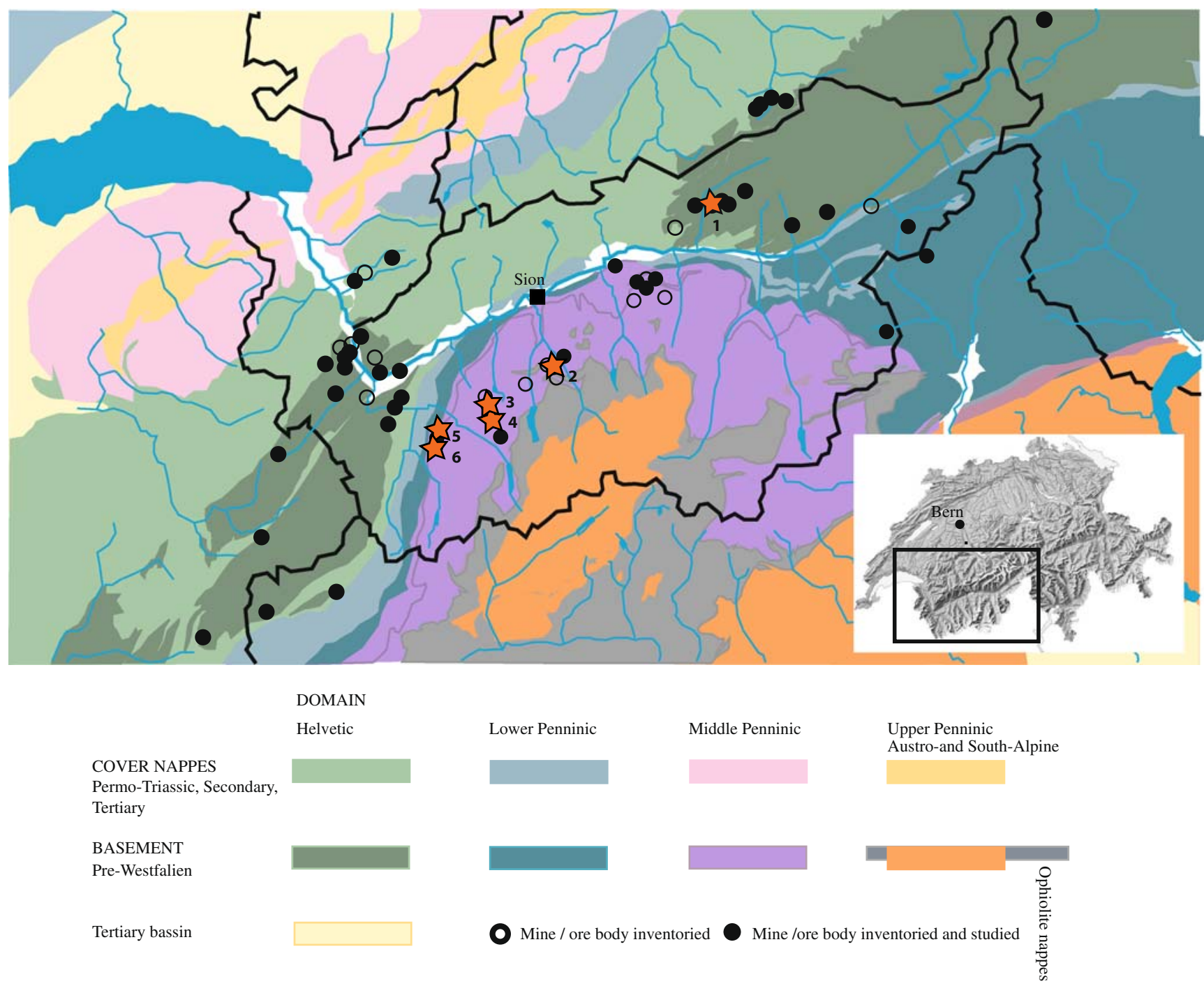

Fig. 2 Tectonic map with lead and silver ore deposits of the studied area. The red stars indicate the most important lead and silver mines ( 1 Goppenstein, 2 Praz Jean, 3 Siviez, 4 Col des Mines, 5 Peiloz, 6 Tête de la Payanne). These six mines are located in the basement

In sourcing studies, it is important to know if the lead isotope field of the studied area overlaps with other mining districts, or if it is unique. To check if the lead isotope characteristics of the Wallis mines are unique, the isotopic compositions of its silver mines have been compared to those of over 60 ore districts in Europe. ${ }^{4}$ The most relevant

\footnotetext{
${ }^{4}$ A database of lead isotope ratios has been compiled of published data for the European ore deposits (France: Marcoux 1986; Brevart et al. 1982; Le Guen et al. 1991; Vogt 2002; Monna 2006 unpublished; Switzerland: Guénette-Beck 2005; Eickenberg et al 1989; Köppel 1997; Mange 1998; Zingg 1989; Austria: Köppel 1997; Köppel and Schroll 1983, 1985; von Quadt 1985; Bulgaria: Stos-Gale et al. 1998; Germany: Gottschalk and Baumann 2001; Krahn and Baumann 1996; Lippolt et al. 1983; Bielicki and Tischendorf 1991; Niederschlag et al. 2003; Durali-Müller 2005; Great Britain: Rohl 1996; Greece: Stos et al. 1996; Spain: Stos et al. 1995; Arribas and Tosdale 1994; Tincherini et al. 2001; Hunt Ortiz 2003; Santos Zalduegui et al. 2004; Italy: Gale and Stos-Gale 1981; Stos et al. 1995; Boni et al. 1992).
}

European mining sites regarding this case study are discussed below. Most mining districts show a very complex geological history with mineralisation taking place at different geological periods. Nevertheless, some metallogenic regions have lead isotope fingerprints clearly different from the Wallis mines (Fig. 4). The formations of the ore bodies of the mines of Carthago Nova (Carthago Nova and Mazarron, Spain), Toscana (Italy), some of the Vosges Mountains (France and Germany) and Schwaz/ Brixlegg (Austria) are much more recent and are linked to the alpine orogenies. The Wallis mines are linked to the Caledonian or Late Hercynian orogenies. For this same reason, the mineralisation of other mines of the Vosges Mountains (France and Germany), Sardinia (Italy), Pontgibaud (France) and Rio Tinto (Spain) have quite different lead isotope fingerprints than the Wallis mines: They are much older than the ore bodies of the Wallis area and are 
Table 1 Lead isotope analyses of lead and silver ores from the Wallis region, Switzerland (Durali-Müller 2005)

\begin{tabular}{|c|c|c|c|c|c|c|c|}
\hline Mine & Mineralisation & $\begin{array}{l}\text { Exploited } \\
\text { metal }\end{array}$ & ${ }^{208} \mathrm{~Pb} /{ }^{204} \mathrm{~Pb}$ & ${ }^{207} \mathrm{~Pb} /{ }^{204} \mathrm{~Pb}$ & ${ }^{206} \mathrm{~Pb} /{ }^{204} \mathrm{~Pb}$ & ${ }^{208} \mathrm{~Pb} /{ }^{206} \mathrm{~Pb}$ & ${ }^{207} \mathrm{~Pb} /{ }^{206} \mathrm{~Pb}$ \\
\hline Goppenstein, Tiebelstollen & Galena & $\mathrm{Pb}, \mathrm{Ag}$ & $38.784 \pm 0.004$ & $15.666 \pm 0.002$ & $18.834 \pm 0.002$ & $2.05918 \pm 0.00004$ & $0.83175 \pm 0.00001$ \\
\hline Goppenstein, Tiebelstollen & Galena & $\mathrm{Pb}, \mathrm{Ag}$ & $38.383 \pm 0.002$ & $15.627 \pm 0.001$ & $18.437 \pm 0.001$ & $2.08181 \pm 0.00005$ & $0.84757 \pm 0.00002$ \\
\hline Goppenstein, Halde & Galena & $\mathrm{Pb}, \mathrm{Ag}$ & $38.478 \pm 0.027$ & $15.635 \pm 0.011$ & $18.512 \pm 0.013$ & $2.07893 \pm 0.00035$ & $0.84465 \pm 0.00006$ \\
\hline Goppenstein, Halde & Galena & $\mathrm{Pb}, \mathrm{Ag}$ & $38.315 \pm 0.025$ & $15.634 \pm 0.008$ & $18.299 \pm 0.012$ & $2.09450 \pm 0.00179$ & $0.85446 \pm 0.00069$ \\
\hline Goppenstein, Halde & Galena & $\mathrm{Pb}, \mathrm{Ag}$ & $38.374 \pm 0.016$ & $15.619 \pm 0.005$ & $18.450 \pm 0.003$ & $2.08002 \pm 0.00049$ & $0.84658 \pm 0.00014$ \\
\hline Goppenstein, Mine 1860 & Galena & $\mathrm{Pb}, \mathrm{Ag}$ & $38.437 \pm 0.005$ & $15.642 \pm 0.001$ & $18.451 \pm 0.001$ & $2.08142 \pm 0.00009$ & $0.84703 \pm 0.00002$ \\
\hline Goppenstein, Mine 1860 & Galena & $\mathrm{Pb}, \mathrm{Ag}$ & $38.410 \pm 0.003$ & $15.635 \pm 0.001$ & $18.445 \pm 0.002$ & $2.08236 \pm 0.00015$ & $0.84772 \pm 0.00006$ \\
\hline Goppenstein, Mine 1860 & Galena & $\mathrm{Pb}, \mathrm{Ag}$ & $38.425 \pm 0.003$ & $15.639 \pm 0.001$ & $18.452 \pm 0.001$ & $2.08253 \pm 0.00009$ & $0.84759 \pm 0.00002$ \\
\hline Goppenstein, Wilerbach & Galena & $\mathrm{Pb}, \mathrm{Ag}$ & $38.467 \pm 0.002$ & $15.634 \pm 0.001$ & $18.488 \pm 0.001$ & $2.08063 \pm 0.00002$ & $0.84565 \pm 0.00001$ \\
\hline Goppenstein, Wilerbach & Galena & $\mathrm{Pb}, \mathrm{Ag}$ & $38.438 \pm 0.003$ & $15.626 \pm 0.001$ & $18.474 \pm 0.001$ & $2.08063 \pm 0.00005$ & $0.84585 \pm 0.00002$ \\
\hline Goppenstein, Schönbiel & Galena & $\mathrm{Pb}, \mathrm{Ag}$ & $38.506 \pm 0.002$ & $15.644 \pm 0.001$ & $18.517 \pm 0.001$ & $2.07942 \pm 0.00004$ & $0.84484 \pm 0.00001$ \\
\hline Praz Jean, La Barma & Galena & $\mathrm{Pb}$ & $38.549 \pm 0.007$ & $15.667 \pm 0.002$ & $18.449 \pm 0.002$ & $2.08957 \pm 0.00019$ & $0.84923 \pm 0.00005$ \\
\hline Praz Jean, La Barma & Galena & $\mathrm{Pb}$ & $38.504 \pm 0.008$ & $15.653 \pm 0.002$ & $18.429 \pm 0.004$ & $2.08941 \pm 0.00025$ & $0.84923 \pm 0.00009$ \\
\hline Praz Jean, La Barma & Galena & $\mathrm{Pb}$ & $38.517 \pm 0.005$ & $15.657 \pm 0.001$ & $18.432 \pm 0.001$ & $2.08975 \pm 0.00016$ & $0.84941 \pm 0.00004$ \\
\hline Praz Jean, La Barma & Galena & $\mathrm{Pb}$ & $38.533 \pm 0.005$ & $15.662 \pm 0.002$ & $18.431 \pm 0.002$ & $2.09042 \pm 0.00011$ & $0.84971 \pm 0.00003$ \\
\hline Praz Jean, La Barma & Galena & $\mathrm{Pb}$ & $38.525 \pm 0.004$ & $15.658 \pm 0.001$ & $18.432 \pm 0.001$ & $2.09007 \pm 0.00009$ & $0.84948 \pm 0.00003$ \\
\hline Praz Jean, La Barma & Galena & $\mathrm{Pb}$ & $38.490 \pm 0.005$ & $15.643 \pm 0.002$ & $18.418 \pm 0.002$ & $2.08970 \pm 0.00018$ & $0.84934 \pm 0.00007$ \\
\hline Praz Jean, La Barma & Galena & $\mathrm{Pb}$ & $38.543 \pm 0.006$ & $15.664 \pm 0.002$ & $18.442 \pm 0.002$ & $2.08993 \pm 0.00008$ & $0.84938 \pm 0.00004$ \\
\hline Praz Jean, La Barma & Galena & $\mathrm{Pb}$ & $38.524 \pm 0.005$ & $15.659 \pm 0.002$ & $18.435 \pm 0.002$ & $2.08984 \pm 0.00008$ & $0.84945 \pm 0.00002$ \\
\hline Praz Jean, La Barma & Galena & $\mathrm{Pb}$ & $38.507 \pm 0.007$ & $15.644 \pm 0.003$ & $18.421 \pm 0.003$ & $2.09072 \pm 0.00012$ & $0.84942 \pm 0.00006$ \\
\hline Siviez & Galena & $\mathrm{Pb}, \mathrm{Ag}$ & $38.482 \pm 0.004$ & $15.656 \pm 0.001$ & $18.432 \pm 0.001$ & $2.08783 \pm 0.00007$ & $0.84935 \pm 0.00002$ \\
\hline Col des Mines & Galena & $\mathrm{Pb}$ & $38.533 \pm 0.010$ & $15.673 \pm 0.003$ & $18.441 \pm 0.002$ & $2.08954 \pm 0.00026$ & $0.84988 \pm 0.00005$ \\
\hline Peiloz & Galena & $\mathrm{Pb}, \mathrm{Ag}$ & $38.347 \pm 0.015$ & $15.637 \pm 0.005$ & $18.317 \pm 0.003$ & $2.09355 \pm 0.00042$ & $0.85370 \pm 0.00009$ \\
\hline Peiloz & Galena & $\mathrm{Pb}, \mathrm{Ag}$ & $38.287 \pm 0.009$ & $15.620 \pm 0.002$ & $18.295 \pm 0.000$ & $2.09274 \pm 0.00026$ & $0.85375 \pm 0.00000$ \\
\hline Peiloz & Galena & $\mathrm{Pb}, \mathrm{Ag}$ & $38.392 \pm 0.009$ & $15.659 \pm 0.034$ & $18.313 \pm 0.002$ & $2.09653 \pm 0.00021$ & $0.85511 \pm 0.00010$ \\
\hline Peiloz & Galena & $\mathrm{Pb}, \mathrm{Ag}$ & $38.382 \pm 0.005$ & $15.655 \pm 0.002$ & $18.311 \pm 0.001$ & $2.09623 \pm 0.00016$ & $0.85501 \pm 0.00003$ \\
\hline Tête de la Payanne & Galena & $\mathrm{Pb}, \mathrm{Ag}$ & $38.365 \pm 0.008$ & $15.638 \pm 0.004$ & $18.367 \pm 0.004$ & $2.08892 \pm 0.00008$ & $0.85459 \pm 0.00006$ \\
\hline Tête de la Payanne & Galena & $\mathrm{Pb}, \mathrm{Ag}$ & $38.333 \pm 0.010$ & $15.629 \pm 0.003$ & $18.351 \pm 0.003$ & $2.08880 \pm 0.00027$ & $0.85165 \pm 0.00006$ \\
\hline Tête de la Payanne & Galena & $\mathrm{Pb}, \mathrm{Ag}$ & $38.364 \pm 0.005$ & $15.637 \pm 0.002$ & $18.363 \pm 0.002$ & $2.08920 \pm 0.00004$ & $0.85151 \pm 0.00002$ \\
\hline
\end{tabular}

linked to Ante-Hercynian mineralisation events. Mineralisations with a similar lead isotope signature, to the abovementioned Wallis mines, are from the Harz Mountains and from the Schwarzwald (partial overlap with the mines of Siviez and Goppenstein). The lead isotope signature from the Bleiberg and partially from the French Alps can be distinguished from the Wallis mines because of the thorogenic influence.

To summarise, this part of the research shows that the lead and silver mineralisations of the Wallis area have been exploited and that their lead isotope signatures are distinguishable from other European mining districts. These conclusions mean that the lead isotope comparisons with the dated artefacts can indicate the periods of their exploitation in ancient times. This leads us to the next part of our results concerning evidence of local production in archaeological artefacts.
Archaeological artefacts produced with metal from local ore

\section{The silver jewels from Randogne-Bluche}

The oldest silver artefacts found in the Wallis area appear during the second part of the Iron Age (LT B2: 300 BC). They appear occasionally at the beginning of the Iron Age and are more frequent at the end of this period (LT D2/ AUG: $30 \mathrm{BC}$ to $\mathrm{AD} 15$ ). The analysed jewels (eight objects: six finger rings and two bracelets; one of them is presented on Fig. 5) were excavated from two tombs in a cemetery located near Randogne-Bluche (Wallis). They date into the LT D2/AUG.

The analytical results illustrated in Fig. 6 and listed in Table 2 show that none of the silver objects analysed are consistent with the lead isotope fingerprint of the ores of 

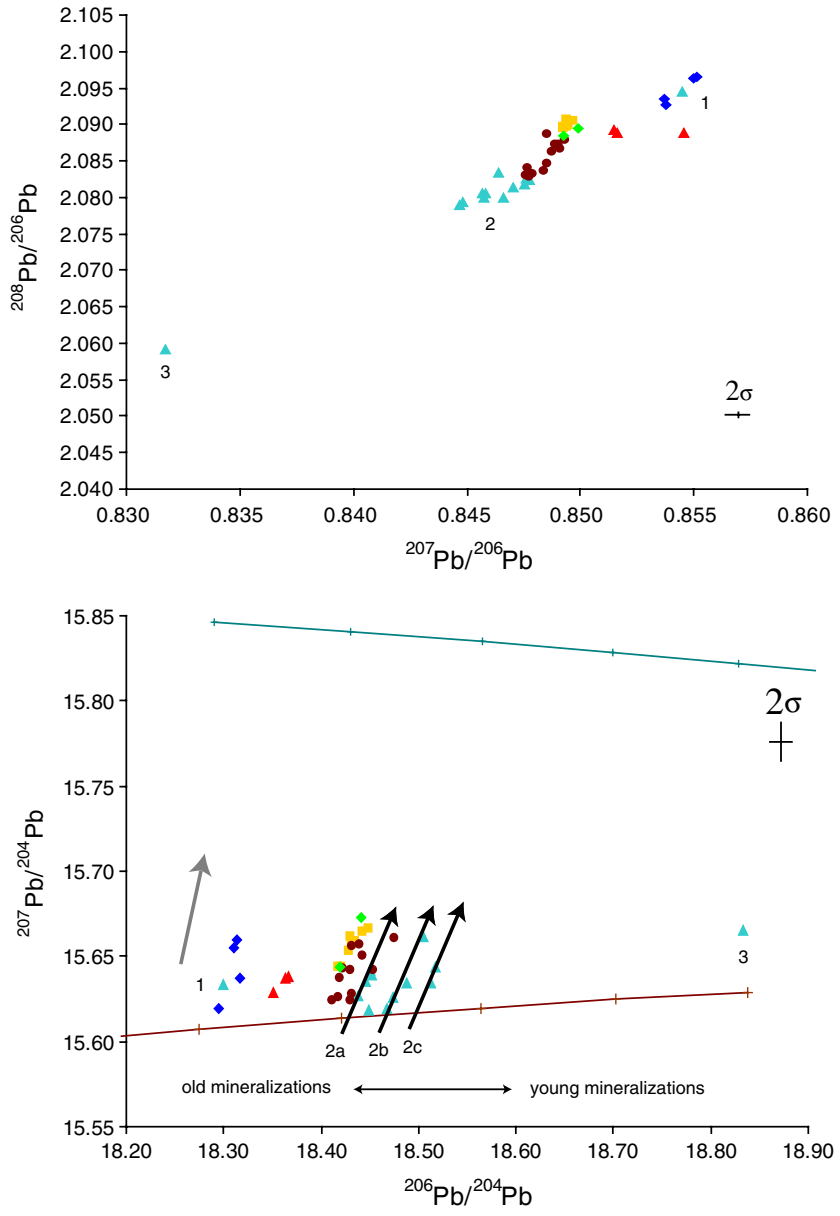

Fig. 3 Diagram of the lead isotope composition of the most important lead and silver ore bodies of the Wallis area, namely of the mines of Goppenstein (light blue triangles), Praz Jean (yellow squares), Siviez (brown circles), Col des Mines (green diamonds), Peiloz (dark blue diamonds) and Tête de la Payanne (red triangles). The values for Goppenstein, Praz Jean, Col des Mines, Peiloz and Tête de la Payanne are listed in Table 1. More data are from Mange (1998, Siviez), Zingg (1989, Goppenstein, Siviez and Col des Mines) and Eickenberg et al. (1989, Siviez). The three mineralisation events of the Goppenstein mines can be distinguished on this plot. The plot ${ }^{207} \mathrm{~Pb} /{ }^{204} \mathrm{~Pb}$ against ${ }^{208} \mathrm{~Pb} /{ }^{204} \mathrm{~Pb}$ permits to explain the formation of the mineralisations of these Wallis mines: lead derived by partial fusion of the upper crust (= brown line: young upper crust); the ore fluid formed in this way is then enriched in lead from the old upper crust (blue line) by lixiviation during metamorphism, before its deposition (Kramers and Tolstikhin 1997). When the ore body is formed by only one mineralisation event, the lead isotope signature shows then one straight tendency (grew arrow). The direction of this arrow is specific for each ore body. It depends on the lixiviated lead, namely on the composition of the lead of the surrounding host rock of the mineralisation. Nearly all studied ore bodies show a linear trend. The main ore body of Goppenstein does not show this tendency; nevertheless, closer examination allows seeing three straight lines, permitting to subdivide this major mineralisation into three close sequenced events $(2 a, 2 b$ and $2 c)$. The identification of this linear trend is a useful tool for characterising an ore body: It allows determining (a) the origin of the mineralisation fluid (in our case the upper crust. Other possibilities are the lower crust or the mantle as described by the model of Kramers and Tolstikhin 1997), (b) the influence of the host rock on the lead isotope composition, (c) the age, the mineralisation was formed (younger mineralisation lies on the right, older in the left) and finally (d) the number of mineralisation events one unique Wallis mine. By including data of other archaeological samples dating also from the end of the Iron Age, namely (1) silver jewellery excavated at other places in the Wallis area (Guénette-Beck 2005) and (2) silver jewellery excavated in the Ticino (Pernet and Carlevaro 2006; Tori et al. 2009), it is partially possible to identify the supplying mining sites.

In Fig. 6, the silver jewellery from the Ticino ${ }^{5}$ area are plotted, classified into four groups depending on their archaeological age.

$>$ The oldest analysed silver jewellery (dark blue diamonds) form a group only in historical sense: They have been handcrafted nearly at the same time (LT B2/ C1: 300-200 BC), but have widespread lead isotope fingerprints. The silver supply is different for each silver artefact.

$>$ The group of silver jewellery from the Ticino area dating to the LT C2/D1 (200-80 BC; pink squares) seems to have a common origin regarding silver supply. All these samples fall in an almost straight line which might indicate that mixed metal of two silver sources have been used for crafting these jewellery.

$>$ The group marked by yellow triangles belongs to the silver jewellery of the Ticino dated into the LT D2 $(80-30 \mathrm{BC})$. The lead isotope fingerprint of these samples is not the same as for the jewellery dating to the LT C2/D1 (pink squares), indicating a change in the silver supply. The data, a little spread, indicate a very heterogeneous silver supply from various sources.

$>$ From Augustan times (30 BC-15 AD), silver supply in the Ticino area seems to be organised again differently (blue squares). The samples seem to be of mixed metal of two silver sources.

It is interesting to discuss the silver jewellery from the Wallis area and namely from Randogne/Bluche (brown triangles in Fig. 6) in relation with the jewellery of the Ticino area because of the strong relationship between these two people attested by the types of archaeological findings (earthenware, silver and bronze jewellery) and by monetised economy (Haldimann 1998; Curdy 1998). The silver supply of the Wallis jewellery is partially similar to the supply of the Ticino jewellery.

$>$ The samples T1-1, T1-2 and three other samples (red circles) from the Wallis area are consistent with the group of the pink rectangles from the Ticino. They

\footnotetext{
${ }^{5}$ For more details about the age and the typology of the silver jewellery, as well as the lead isotopic interpretation, see Tori et al. (2009).
} 
Fig. 4 Plot of the lead isotope fingerprints of the Wallis mines in comparison to those of some other European mines. Blue: Lead isotope ratios from Italian Mines (Tuscany, Sardinia); green: from Spanish Mines (Carthago Nova, Rio Tinto); pink: from Germany (Harz Mountains); yellow: from Austria (Bleiberg); grew: from France (Vosges Mountains and Pontgibaud); red: lead isotope ratios from Switzerland (Wallis mines). For references to the data, cf. footnote 4
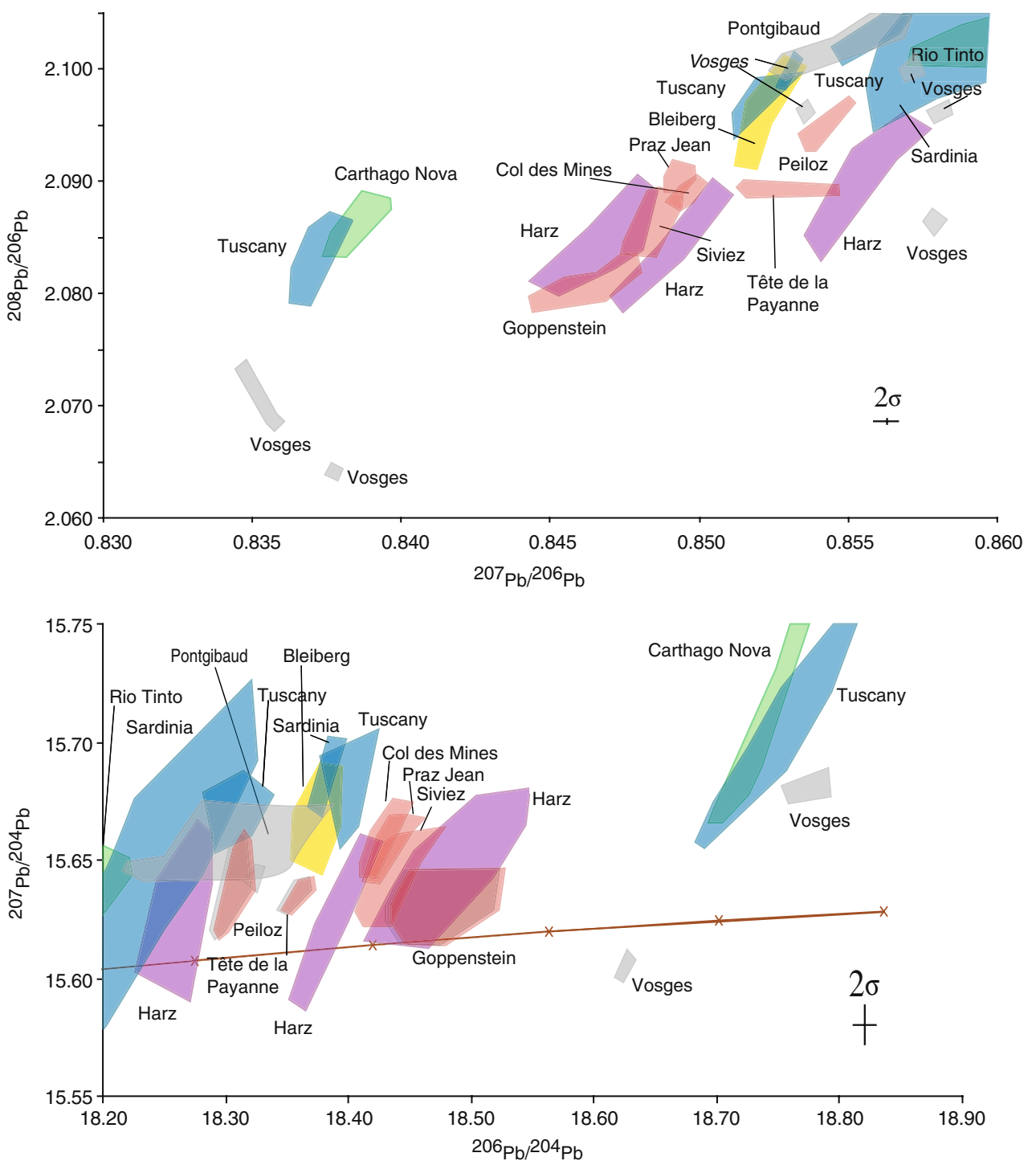

are almost contemporary: The Wallis samples (red circles) date from the LT D (150-30 BC), whereas the Ticino samples from the LT C2/D1 (200-80 BC). The silver seems to be a mix of silver metal from two sources with variable proportions. None of the
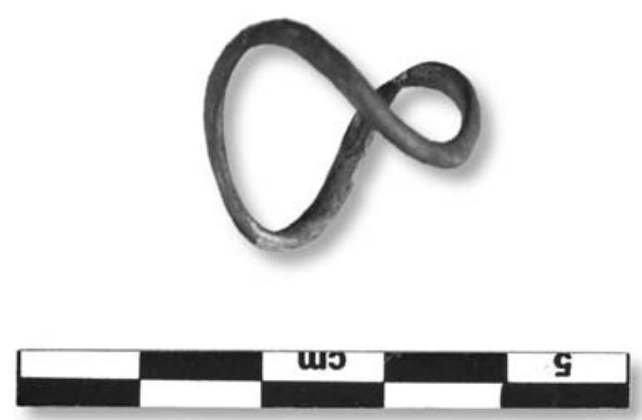

Fig. 5 One silver artefact (sample no. T1-3) from a tomb in Randogne-Bluche, Late Iron Age (30 BC to AD 15). Photos: Aria SA, Sion
Wallis ore seems to be consistent to one of these sources. ${ }^{6}$

$>$ The samples T1-4, T1-5 and T4-40 from RandogneBluche have a different lead isotope fingerprint than all other studied samples of Augustan times: The samples from the Ticino (blue squares) and maybe from some other places in the Wallis area (red circles) are characterised by another source of metal supply than the samples from Randogne-Bluche. The last ones lie on an almost straight line. ${ }^{7}$ At one end, the isotopic composition does not correspond to a local mine. ${ }^{8}$ The

\footnotetext{
${ }^{6}$ Based upon lead isotope analyses and archaeology, the silver provenance from the Vosges Mountains is possible.

${ }^{7}$ Provenance of silver from the Tuscany (Italy) cannot be excluded. This would corroborate archaeological findings, proving an orientation of the Wallis and the Ticino towards the south.

${ }^{8}$ The isotopic composition corresponds well to that of ore samples from the mines of Carthago Nova (Spain) or the mines in the Tuscany (Italy) respectively. It is not possible to distinguish between these two on the basis of lead isotopes.
} 
Fig. 6 Results of the lead isotope analyses of the silver jewellery (brown triangles) found in Randogne-Bluche (Wallis, Switzerland), illustrated in their isotopic (mines of the Wallis area: light grey fields) and archaeological context (jewellery from the Wallis: red circles dated between $300 \mathrm{BC}$ and $15 \mathrm{AD}$. Jewellery from the Ticino: dark blue diamonds dated between 300 and 200 BC; pink squares dated between 20 and $80 \mathrm{BC}$; yellow triangles dated between 80 and $30 \mathrm{BC}$; blue squares dated from Augustan times.). The brown curve indicates the evolution line of a lead from the young upper crust (after the model of Kramers and Tolstikhin 1997)
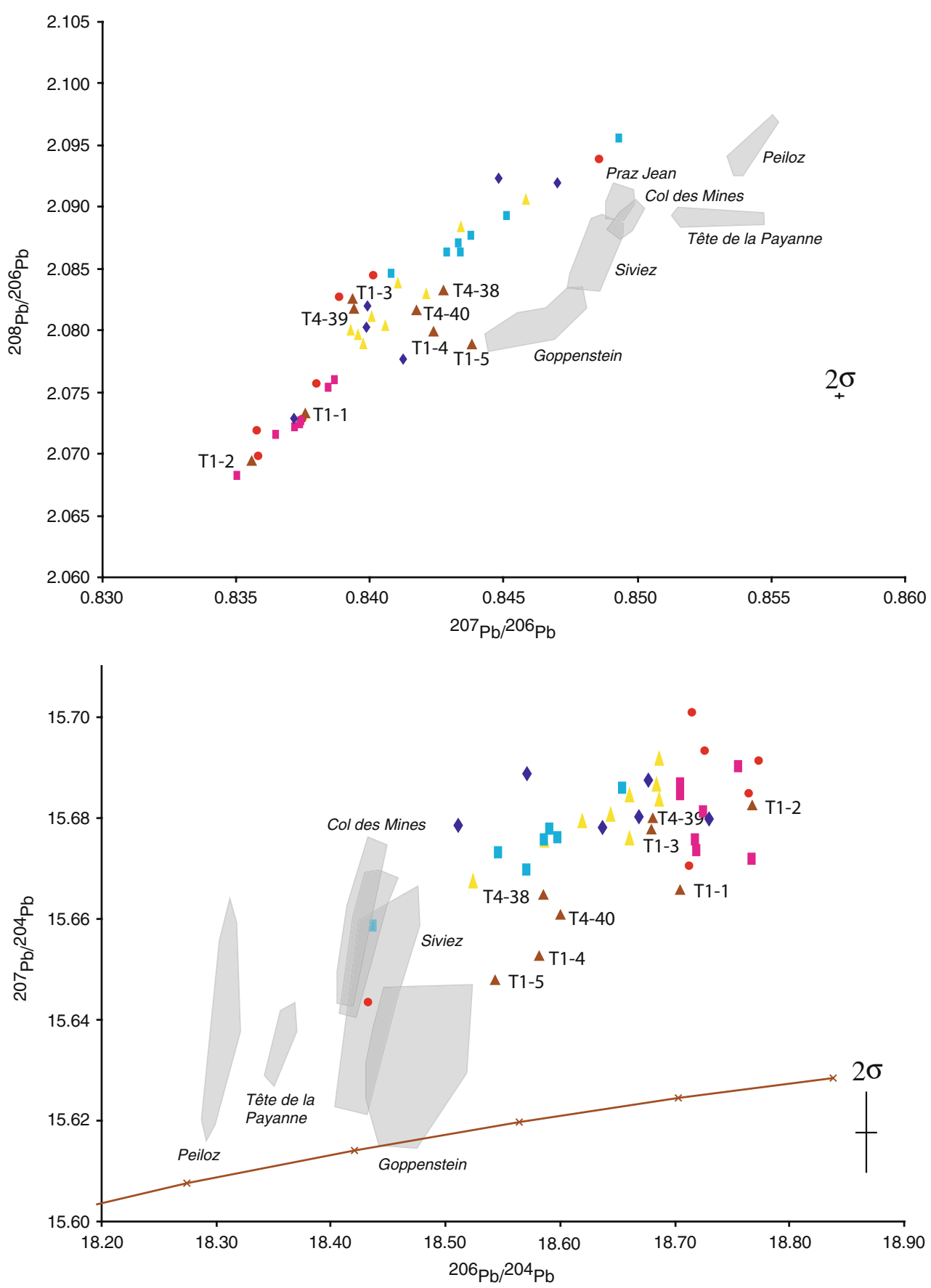

values on the other end correspond very well to those obtained for the mines of Goppenstein, situated in the studied area. There are still other possibilities for metal provenance than the mines of Goppenstein: The Harz Mountains and the Schwarzwald host ore bodies with similar lead isotope characteristics. However, as this source does not seem to be known in the adjacent regions of the Wallis area, namely the Ticino and the Swiss midland (cf. coins discussed in Fig. 9), we can propose the hypothesis that the silver jewellery from Randogne-Bluche are made from silver originating partly from the local mines, namely the mines of Goppenstein.

$\gg$ There are samples which cannot be attributed definitely to one of the above described group. The samples T1-3 and T4-39 from Randogne/Bluche might be similar to the samples T1-4, T1-5 and T4-40 discussed before. Sample T4-38 cannot be interpreted in terms of lead isotopes.

We can determine at least two different periods of silver supply in the Wallis region. During the LT D, the silver supply seems to be supra-regional, because we found 
Table 2 Lead isotope analyses of the reliquary shrine of the infants of Saint Sigismund, Abbey of St Maurice, Switzerland

\begin{tabular}{llllllll}
\hline Analyse no. & Description & Locality & ${ }^{208} \mathrm{~Pb} /{ }^{204} \mathrm{~Pb}$ & ${ }^{207} \mathrm{~Pb} /{ }^{204} \mathrm{~Pb}$ & ${ }^{206} \mathrm{~Pb}{ }^{204} \mathrm{~Pb}$ & ${ }^{208} \mathrm{~Pb} /{ }^{206} \mathrm{~Pb}$ & ${ }^{207} \mathrm{~Pb} /{ }^{206} \mathrm{~Pb}$ \\
\hline T1-1 & Bangle & Tomb 1 & $38.775 \pm 0.003$ & $15.666 \pm 0.001$ & $18.707 \pm 0.001$ & $2.07276 \pm 0.00005$ & $0.83748 \pm 0.00002$ \\
T1-2 & Bangle & Tomb 1 & $38.840 \pm 0.004$ & $15.682 \pm 0.001$ & $18.768 \pm 0.002$ & $2.06944 \pm 0.00004$ & $0.83558 \pm 0.00002$ \\
T1-3 & Bangle & Tomb 1 & $38.903 \pm 0.002$ & $15.678 \pm 0.001$ & $18.679 \pm 0.001$ & $2.08255 \pm 0.00006$ & $0.83936 \pm 0.00001$ \\
T1-4 & Bangle & Tomb 1 & $38.647 \pm 0.002$ & $15.653 \pm 0.001$ & $18.582 \pm 0.001$ & $2.07986 \pm 0.00005$ & $0.84236 \pm 0.00001$ \\
T1-5 & Bracelet & Tomb 1 & $38.560 \pm 0.002$ & $15.652 \pm 0.001$ & $18.547 \pm 0.001$ & $2.07912 \pm 0.00004$ & $0.84389 \pm 0.00001$ \\
T4-38 & Bangle & Tomb 4 & $38.724 \pm 0.004$ & $15.665 \pm 0.002$ & $18.586 \pm 0.002$ & $2.08330 \pm 0.00005$ & $0.84276 \pm 0.00002$ \\
T4-39 & Bangle & Tomb 4 & $38.886 \pm 0.003$ & $15.680 \pm 0.001$ & $18.680 \pm 0.001$ & $2.08170 \pm 0.00005$ & $0.83938 \pm 0.00001$ \\
T4-40 & Bracelet & Tomb 4 & $38.733 \pm 0.016$ & $15.661 \pm 0.006$ & $18.600 \pm 0.008$ & $2.08165 \pm 0.00010$ & $0.84175 \pm 0.00004$ \\
\hline
\end{tabular}

They date into the LT D2/AUG (30 BC-AD 15)

silver artefacts with the same isotopic fingerprint in the adjacent area, namely the Ticino. During Augustan times, we observe also a regional silver supply, since metal from the Goppenstein mines have only been handcrafted for silver jewellery from Randogne/Bluche.

The case study of the silver jewellery from the Ticino area showed a strong correlation between lead isotope signature and archaeological age. This is not the case for the jewellery from Randogne/Bluche: All these artefacts have been crafted at the same time (Augustan times: 30 BC-AD 15), but show two different silver supplies. The one is in use during the LT D, the other one later on during the LT D2/AUG. This seems to indicate that some of these objects have been made of old, re-melted silver.

\section{The reliquary shrine of the infants of Saint Sigismund}

The silver shrine of the infants of Saint Sigismund (Fig. 7) is part of the treasure of the Abbey of Saint Maurice in the Wallis. Its name refers to the relic of the Burgundian King Sigismund, founder of the abbey in $515 \mathrm{AD}$, and his two sons. This prestigious reliquary up until the present day continues to be carried in a procession once a year during the patronal ceremony of Saint Maurice. It was initially crafted in the twelfth century. Historic and stylistic studies suggest local

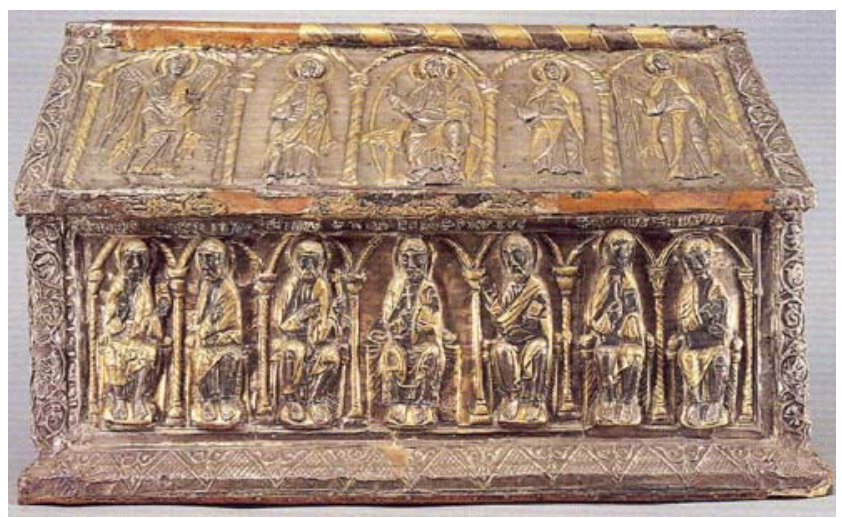

Fig. 7 The shrine of the infants of Saint Sigismund. Photo: D. Thurre craftsmanship for this shrine. Because of its alarming condition, the shrine was restored from 1998 to 2007, which permitted a systematic study of its conservation/restoration, history, style and composition (Schweizer and Witschard 2007).

The results of the isotopic analyses, illustrated in Fig. 8 and listed in Table 3, distinguish two groups (Guénette-Beck 2007). The first group includes five samples from three sides (red squares) and two mouldings (yellow triangles). The results show that these samples have very similar isotopic compositions. Such strong concordance between the isotopic fingerprints can be explained in two ways: (1) Their isotopic compositions match that of the ores from one mine. Therefore, the silver originated from one single source or one specific mine. In the Wallis area, no mine has a similar isotopic fingerprint. Since the Wallis as a metallogenic region is very well documented, it can be excluded as a possible source area. There are silver mines with comparable isotopic composition in Europe, active at the same time as this shrine was made. ${ }^{9}$ Nevertheless, it is difficult to select a mine or mining district and interpret an undisputable result based only on lead isotope analyses. (2) The tiles were created from one single mixture of metals which, however, originated from more than one source. This hypothesis is only plausible if the different tiles were fabricated with the same batch of silver. In this case, the tiles must have been fabricated at the same time in the same workshop. If the silver used for coin melting originated from more than one metal source, it is extremely difficult to identify the different sources as they may have included the re-melting of ancient silverware, made of material from local mines, or from mines in the border regions or elsewhere in Europe.

The second group contains tiles from two gables (blue triangles), two tiles (dark blue diamonds) and one piece repairing the moulding (yellow triangle) discussed in the first group. The isotopic composition of these samples is completely different from those of the first group. The analyses show an

\footnotetext{
${ }^{9}$ Possible ore sources are namely mines from the Schwarzwald or the Bohemian Massif.
} 
Fig. 8 Plot of the lead isotope data of samples obtained from the silver shrine of the infants of Saint Sigismund. The values of group 1 (five samples from three sides (red squares) and from two mouldings (yellow triangles; one moulding has been analysed twice)) - show a very homogenous isotopic signature, whereas the ones of group 2 (five samples from two gables (blue triangles), two tiles of the lid (dark blue diamonds) and one piece repairing a moulding (yellow triangle)) might indicate a poly-metal source. The grey fields indicate the lead isotope fingerprint of the most important mines of the Wallis area
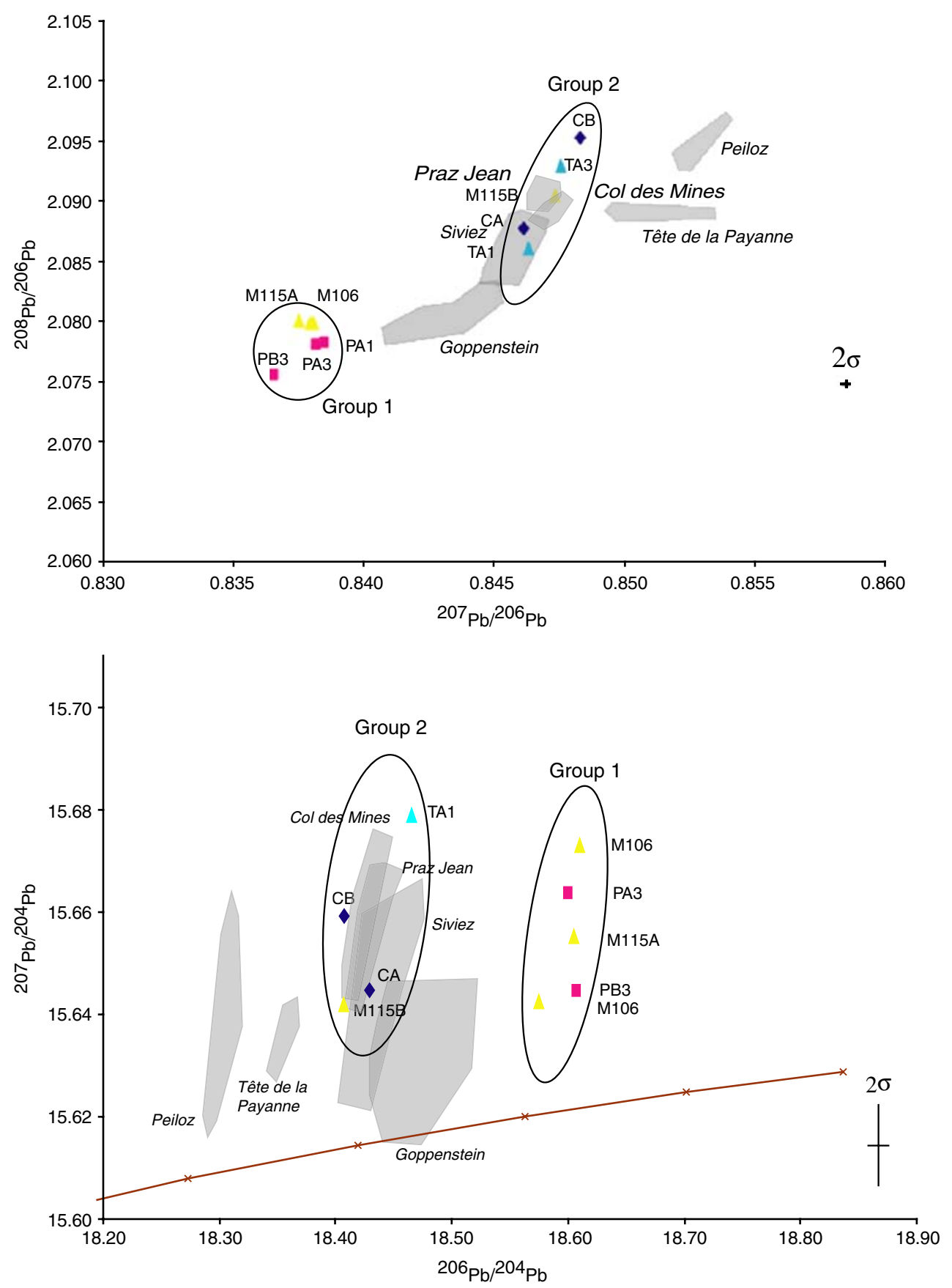

alignment in the plot ${ }^{207} \mathrm{~Pb} /{ }^{206} \mathrm{~Pb}$ versus ${ }^{208} \mathrm{~Pb} /{ }^{206} \mathrm{~Pb}$ (Fig. 8). The same analyses show a slightly dispersed group without any alignment in the plot ${ }^{206} \mathrm{~Pb} /{ }^{204} \mathrm{~Pb}$ versus ${ }^{207} \mathrm{~Pb} /{ }^{204} \mathrm{~Pb}$; this is the reason why they cannot be characteristic from an ore source formed by a single mineralisation event. This group of silver artefacts was elaborated with metal from at least two possible sources. We can almost entirely exclude the local mines as possible origins of the metal. ${ }^{10}$

\footnotetext{
${ }^{10}$ The lower points on the ${ }^{207} \mathrm{~Pb} /{ }^{206} \mathrm{~Pb}$ versus ${ }^{208} \mathrm{~Pb} /{ }^{206} \mathrm{~Pb}$ diagram of this group are consistent with silver from the Harz Mountains and from the Massif Central.
}

The silver of these two groups of samples has very different origin. This suggests that the different ornaments on the chest were crafted at different times, possibly over a short time span. Furthermore, the relationship between moulding and its reparation allows to determine the relative age of the two groups. In this case, the samples of the first group have been crafted before the samples of the second group: The piece M 115B repairs the moulding M 115A (Fig. 8).

Although the shrine is assumed to have been crafted by a local silversmith, the metal worked into the artefact is unlikely to have originated from a local mine. Metal 
Table 3 Lead isotope analyses of the silver jewellery from Randogne-Bluche, Wallis, Switzerland

\begin{tabular}{lllllll}
\hline Analyse no & Description & ${ }^{208} \mathrm{~Pb} /{ }^{204} \mathrm{~Pb}$ & ${ }^{207} \mathrm{~Pb} /{ }^{204} \mathrm{~Pb}$ & ${ }^{206} \mathrm{~Pb} /{ }^{204} \mathrm{~Pb}$ & ${ }^{208} \mathrm{~Pb} /{ }^{206} \mathrm{~Pb}$ & ${ }^{207} \mathrm{~Pb}{ }^{206} \mathrm{~Pb}$ \\
\hline PA1 & Side A & nd & nd & nd & $2.07831 \pm 0.00014$ & $0.84256 \pm 0.00004$ \\
PA3 & Side A & $38.645 \pm 0.004$ & $15.665 \pm 0.002$ & $18.596 \pm 0.002$ & $2.07811 \pm 0.00002$ & $0.84231 \pm 0.00001$ \\
PB3 & Side B & $38.616 \pm 0.004$ & $15.645 \pm 0.001$ & $18.603 \pm 0.001$ & $2.07574 \pm 0.00008$ & $0.84099 \pm 0.00002$ \\
M 106 & Moulding & $38.695 \pm 0.054$ & $15.674 \pm 0.021$ & $18.607 \pm 0.025$ & $2.08007 \pm 0.00016$ & $0.84221 \pm 0.00010$ \\
M 106 & Moulding & $38.626 \pm 0.048$ & $15.643 \pm 0.018$ & $18.573 \pm 0.022$ & $2.07994 \pm 0.00023$ & $0.84213 \pm 0.00013$ \\
M 115A & Moulding & $38.695 \pm 0.004$ & $15.658 \pm 0.001$ & $18.603 \pm 0.001$ & $2.08019 \pm 0.00010$ & $0.84178 \pm 0.00002$ \\
M 115B & Moulding & $38.486 \pm 0.003$ & $15.644 \pm 0.001$ & $18.410 \pm 0.002$ & $2.09058 \pm 0.00003$ & $0.84975 \pm 0.00001$ \\
CA & Lid A & $38.481 \pm 0.020$ & $15.645 \pm 0.009$ & $18.430 \pm 0.009$ & $2.08784 \pm 0.00018$ & $0.84879 \pm 0.00009$ \\
CB & Lid B & $38.580 \pm 0.009$ & $15.661 \pm 0.004$ & $18.411 \pm 0.004$ & $2.09528 \pm 0.00004$ & $0.85054 \pm 0.00003$ \\
TA1 & Gable A & $38.532 \pm 0.029$ & $15.681 \pm 0.012$ & $18.466 \pm 0.015$ & $2.08612 \pm 0.00020$ & $0.84896 \pm 0.00007$ \\
TA3 & Gable A & nd & nd & nd & $2.09308 \pm 0.00020$ & $0.84995 \pm 0.00008$ \\
\hline
\end{tabular}

${ }^{\text {a }}$ Piece repairing the moulding M $115 \mathrm{~A}$

from more than one source is suggested by lead isotope for the second group, possibly also for the first group. According to historical texts, the re-melting of votive offerings is often made when larger quantities of metal are needed for religious silversmithing (Schweizer and Witschard 2007).

\section{Medieval coins, minted in the Wallis}

The pinnacle of silver minting occurred during the Episcopal period. The analysed coins belong to the first pieces minted by freshly invested bishops, namely the coins (Fig. 9) of Mathieu Schiner (four pieces analysed, minted in 1499-1522), Adrien I de Riedmatten (three pieces, 1542), Jean Jordan (two pieces, 1549), Jost Hildebrand (one piece, 1624), François-Joseph Supersaxo (two pieces, 1710) and François-Frédéric Ambuel (three pieces, 1777)

The lead isotope analyses of these coins indicate a metal supply changing in time (Table 4; Fig. 10, brown squares).

(a) The coins $\mathrm{M} 1257, \mathrm{M} 1253, \mathrm{M} 1256, \mathrm{M} 1254, \mathrm{M}$ 4362, M 1266, M 1267, M 1272 and M 1273 minted

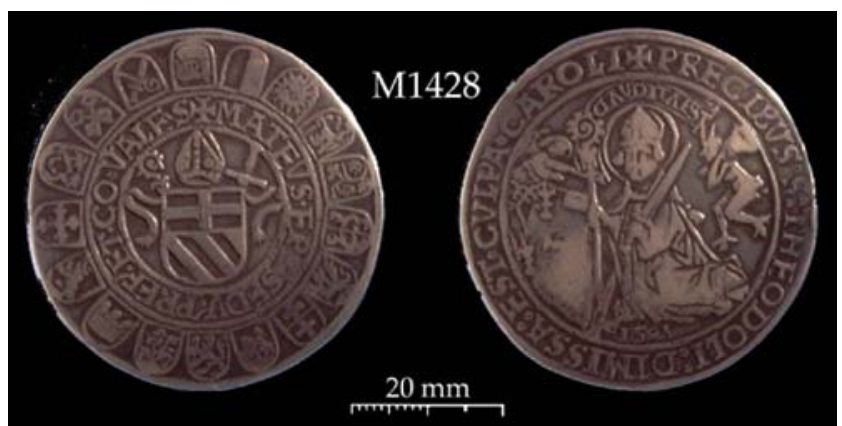

Fig. 9 Silver thaler minted in the Wallis by the bishop Matthias Schiner in 1501. Photo: Museum of History, Sion by the first three bishops between 1499 and 1549 show a very homogenous lead isotope fingerprint, suggesting a supply of silver from one particular source. It matches perfectly with that of ore samples from the local silver mines of Peiloz.

(b) The analysis no. M 1303, a coin minted by bishop Hildebrand Jost in 1624, cannot be interpreted in terms of lead isotope; the dataset is insufficient.

(c) The metal used for minting by the bishop FrançoisJoseph Supersaxo in 1710 (sample nos. M 6807 and 6808 ) is consistent with a metal supply from one source. The silver is certainly not from a Wallis mine. ${ }^{11}$

(d) The three analysed coins (M 6813, M 6814 and M 6822) minted by the bishop François-Frédéric Ambuel in 1777 are very heterogeneous in lead isotopes. Their fingerprint is consistent with a mix of metals from different mines. Possible sources of metal are re-melted silver coins minted until 1549 with silver from the mines of Peiloz, on the one hand, and with silver used by François-Joseph Supersaxo, on the other hand.

In Fig. 10, there are plotted also 25 data points for coins dated between the end of the Iron Age and the Middle Ages circulating in the Wallis (blue triangles and red circles) and adjacent area (green triangles and yellow diamonds). Their isotopic fingerprints are incompatible with a silver supply from a local mine, except some of the coins minted from the ninth to the fourteenth centuries (blue triangles), whose lead isotope fingerprint may be partially consistent with those of the mines of Tête de la Payanne, situated close to the mines of Peiloz (for more details, see Guénette-Beck 2005).

\footnotetext{
${ }^{11}$ The lead isotope fingerprint of these two coins is consistent with those from the Schwarzwald or the Bohemian Massif.
} 
Table 4 Lead isotope analyses of the Episcopal silver coins minted in the Wallis area, Switzerland

\begin{tabular}{|c|c|c|c|c|c|c|c|}
\hline Analyse no. & Coins & Coinage authority & ${ }^{208} \mathrm{~Pb} /{ }^{204} \mathrm{~Pb}$ & ${ }^{207} \mathrm{~Pb} /{ }^{204} \mathrm{~Pb}$ & ${ }^{206} \mathrm{~Pb} /{ }^{204} \mathrm{~Pb}$ & ${ }^{208} \mathrm{~Pb} /{ }^{206} \mathrm{~Pb}$ & ${ }^{207} \mathrm{~Pb} /{ }^{206} \mathrm{~Pb}$ \\
\hline M 1253 & Dicken & $\begin{array}{l}\text { Bishop Mathieu } \\
\text { Schiner }\end{array}$ & $38.406 \pm 0.003$ & $15.660 \pm 0.001$ & $18.310 \pm 0.001$ & $2.09768 \pm 0.00009$ & $0.85535 \pm 0.00003$ \\
\hline M 1256 & Dicken & $\begin{array}{l}\text { Bishop Mathieu } \\
\text { Schiner }\end{array}$ & $38.357 \pm 0.003$ & $15.644 \pm 0.001$ & $18.304 \pm 0.001$ & $2.09548 \pm 0.00007$ & $0.85466 \pm 0.00002$ \\
\hline M 1257 & Dicken & $\begin{array}{l}\text { Bishop Mathieu } \\
\text { Schiner }\end{array}$ & $38.410 \pm 0.005$ & $15.652 \pm 0.002$ & $18.324 \pm 0.003$ & $2.09616 \pm 0.00013$ & $0.85414 \pm 0.00006$ \\
\hline M 1254 & Six-gros & $\begin{array}{l}\text { Bishop Mathieu } \\
\text { Schiner }\end{array}$ & $38.356 \pm 0.004$ & $15.646 \pm 0.002$ & $18.303 \pm 0.002$ & $2.09564 \pm 0.00004$ & $0.85483 \pm 0.00002$ \\
\hline M 1268 & Demi-dicken & $\begin{array}{c}\text { Bishop Adrien I } \\
\text { de Riedmatten }\end{array}$ & $38.387 \pm 0.007$ & $15.656 \pm 0.003$ & $18.309 \pm 0.004$ & $2.09633 \pm 0.00011$ & $0.85499 \pm 0.00004$ \\
\hline M 1266 & Demi-dicken & $\begin{array}{l}\text { Bishop Adrien I } \\
\text { de Riedmatten }\end{array}$ & $38.355 \pm 0.004$ & $15.644 \pm 0.002$ & $18.296 \pm 0.002$ & $2.09633 \pm 0.00015$ & $0.85502 \pm 0.00007$ \\
\hline M 1267 & Demi-dicken & $\begin{array}{l}\text { Bishop Adrien I } \\
\text { de Riedmatten }\end{array}$ & nd & nd & nd & $2.13014 \pm 0.00613$ & $0.86877 \pm 0.00235$ \\
\hline M 1272 & Dicken & Bishop Jean Jordan & $38.377 \pm 0.007$ & $15.653 \pm 0.003$ & $18.314 \pm 0.003$ & $2.09559 \pm 0.00005$ & $0.85472 \pm 0.00002$ \\
\hline M 1273 & Dicken & Bishop Jean Jordan & $38.359 \pm 0.002$ & $15.642 \pm 0.002$ & $18.316 \pm 0.001$ & $2.09440 \pm 0.00003$ & $0.85404 \pm 0.00007$ \\
\hline M 1303 & Demi-thaler & $\begin{array}{l}\text { Bishop Hildebrand } \\
\text { Jost }\end{array}$ & $38.457 \pm 0.002$ & $15.631 \pm 0.001$ & $18.491 \pm 0.001$ & $2.07975 \pm 0.00005$ & $0.84533 \pm 0.00002$ \\
\hline M 6807 & Vingt-kreuzer & $\begin{array}{l}\text { Bishop François- } \\
\text { Joseph Supersaxo }\end{array}$ & $38.565 \pm 0.002$ & $15.642 \pm 0.001$ & $18.571 \pm 0.001$ & $2.07667 \pm 0.00004$ & $0.84231 \pm 0.00001$ \\
\hline M 6808 & Vingt-kreuzer & $\begin{array}{l}\text { Bishop François- } \\
\text { Joseph Supersaxo }\end{array}$ & $38.552 \pm 0.008$ & $15.634 \pm 0.003$ & $18.569 \pm 0.004$ & $2.07612 \pm 0.00003$ & $0.84189 \pm 0.00002$ \\
\hline M 6813 & Vingt-kreuzer & $\begin{array}{l}\text { Bishop François- } \\
\text { Frédéric Ambuel }\end{array}$ & $38.378 \pm 0.002$ & $15.627 \pm 0.001$ & $18.378 \pm 0.001$ & $2.08811 \pm 0.00003$ & $0.85026 \pm 0.00001$ \\
\hline M 6814 & Vingt-kreuzer & $\begin{array}{l}\text { Bishop François- } \\
\text { Frédéric Ambuel }\end{array}$ & $38.502 \pm 0.003$ & $15.639 \pm 0.002$ & $18.497 \pm 0.001$ & $2.08160 \pm 0.00005$ & $0.84555 \pm 0.00002$ \\
\hline M 6822 & Vingt-kreuzer & $\begin{array}{l}\text { Bishop François- } \\
\text { Frédéric Ambuel }\end{array}$ & $38.522 \pm 0.011$ & $15.641 \pm 0.004$ & $18.475 \pm 0.005$ & $2.08523 \pm 0.00011$ & $0.84663 \pm 0.00004$ \\
\hline
\end{tabular}

Silver production from the local mines is attested with certainty only for the Episcopal minting. Historical documents attest that the bishop of Sion acquired the mines of Peiloz, located in the Bagnes valley, in 1475 (Payot 2000). These mines are known for their very high-grade silver content (Ansermet and Meisser 1996) and have been exploited for minting until at least 1549 , as shown by lead isotope studies. The currently available dataset is not possible to date the change in the silver supply, which is evident from 1624 (minting of bishop Hildebrand Jost) onwards. Based upon historical texts (Elsig 1993), the silver supply for the mint with re-melted old coins and silverware is usual from this time on. This change in the procurement of the metal for the production of coins were influenced by the political strife that touched the Wallis, resulting in the end of Episcopal power with the attribution of the Wallis to the civic sovereignty in 1634 and, also at the same time, losing his sovereign right over mining resources. However, it is also possible that the mines of Peiloz produced less because the ore vein was completely worked out in 1723 .

This case study permits the question to be raised about lead isotope analyses on coins in general. In fact, when minting silver coins, it is not unusual to use re-melted old coins. This poses two major difficulties for isotopic origin studies. On the one hand, the re-melted silver may be a mixture of metal from more than one source so the isotopic signature shows a very heterogeneous spectrum which is not easy to interpret (as in the above-discussed case (d)). On the other hand, the silver of re-melted coins can be purified, allowing better control of the silver content. When the silver undergoes a purifying cupellation, lead has to be added in large quantities to the remelted silver. Therefore, the ensuing analysis does not necessarily reflect the lead isotope composition of the original silver but of the added lead.

\section{Conclusions}

The study of the metallogenic region of the Wallis area, coupled with a sourcing study of historical and archaeological artefacts by lead isotopes, brings new insights into the exploitation history of the silver mines from the Late Iron Age to the Late Middle Ages. It is known from the historical documents that in the recent times, the mines in the Wallis were exploited for silver production. For older periods, the earliest use of the local silver supply can now be dated to the Final Iron Age (LT D2/AUG: 30 BC-AD 15). This does not correspond to the oldest silver artefact, jewellery found in the studied area and dated to the LT B2 
Fig. 10 Results of the lead isotope analyses of the Episcopal silver coins (brown squares, the numbers refer to Table 4) illustrated in a possible isotopic context: the most important mines of the Wallis area (in grey). Red circles: coins circulating in the Wallis area during the end of the Iron Age. Green triangles: coins circulating in the adjacent area at the end of the Iron Age. Yellow diamonds: Potin coins circulating in the adjacent area at the end of the Iron Age. Blue triangles: coins minted from the ninth to the fourteenth centuries in the Wallis. The brown curve indicates the evolution line of a lead from the young upper crust (after the model of Kramers and Tolstikhin 1997)
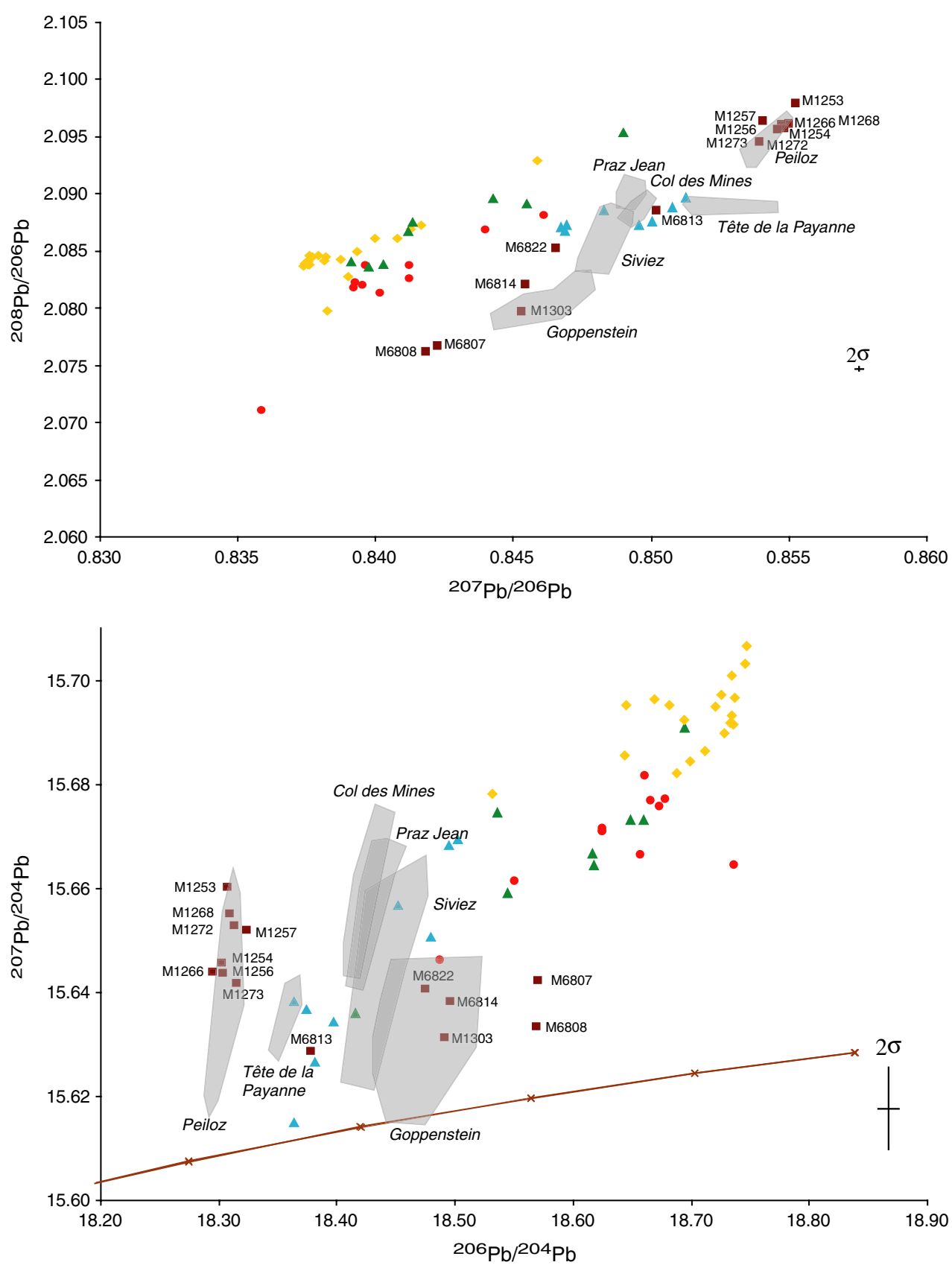

(300-250 BC) but to the period to which most of the silver objects found in the area can be dated (LT D2/AUG).

During the Early Middle Ages, the history of silver supply becomes complex. Depending on the usage, the silver is either imported or re-melted (for jewellery or religious art), or extracted from the local mines (for minting coins). The local silver production was controlled by the minting authorities, namely the bishops of Sion. For this period, the local mining activity can now be specified: The local mines were exploited for minting, probably from the ninth century onwards (Tête de la Payanne mines). Mining continued during the High and Late Middle Ages (Peiloz mines), and finally, from the sixteenth century onwards, local production ceases.
Regarding the history of export of silver from the Wallis mines, little is known. Evidence has only been found from the Late Iron Age of the southern part of Switzerland (Ticino) where several silver jewellery pieces were excavated (Pernet and Carlevaro 2006), some of them in the previously mentioned typical Wallis style. One of these artefacts (cf. Fig. 6, blue diamond close to the Goppenstein mine) might show a compatible isotopic fingerprint to the Wallis mine of Goppenstein (Tori et al. 2009). No other silver artefact, namely silver coins of the same period and circulating outside of the Wallis region, could so far be related to the Wallis mines. During Roman times, the local silver production was insignificant, and in 
the Middle Ages, silver production was under the very strict control of the local minting authorities, namely the bishop of Sion.

Acknowledgements This research was supported by the Swiss National Science Foundation, the cantonal museums of the Wallis (M.-C. Morand, Ph. Curdy, P. Elsig), « le fondation pour la restauration de deux chefs d'oeuvre d'orfèvrerie médiévale en Valais » (F. Schweizer and K. Anhäuser) and The Geological Museum of Lausanne (N. Meisser and S. Ansermet).

\section{References}

Ansermet S, Meisser N (1996) Travaux préliminaires sur la mine d'argent de Peiloz, Bruson, Val de Bagnes. Min Helv 16a:61-67

Ansermet S, Meisser N (1997) Découverte de trios nouvelles occurrences d'argent natif en Suisse. Cristallier suisse 11(1):7-10

Arribas AJ, Tosdale R (1994) Isotopic composition of $\mathrm{Pb}$ in Ore deposits of the Betic Corillera Spain: origin and relationship to other European deposits. Econ Geol 89:1074-1093

Bielicki KH, Tischendorf G (1991) Lead isotope and $\mathrm{Pb}-\mathrm{Pb}$ model age determinations of ores from central Europe and their metallogenetic interpretation. Contrib Mineral Petrol 106:440-461

Boni M, Innace A, Köppel V, Früh-Green G, Hansmann W (1992) Late to post-Hercynian hydrothermal activity and mineralization in southwest Sardinia (Italy). Econ Geol 87:2113-2137

Brevart O, Dupré B, Allègre CJ (1982) Metallogenic provinces and the remobilization process studied by lead isotopes. Lead-zinc ore deposits from the southern Massif Central. France Econ Geol 77:564-575

Bugnon C (1983) Fiches descriptives des anciennes mines du Massif des Aiguilles Rouges, du Lötschental et du Pennique dans la région du Val Ferret au Val d'Hérens. Rapport interne Uromine

Cavalli D, Haldemann EG, Kündig R, Reber D, Rouiller JD, Schafer M (1998) Carte des matières premières minérales de la Suisse, 1:200 000, Feuille 2. Commission Géotechnique Suisse, Zurich

Curdy P (1998) La population locale: Alpins et Celtes. Vallis Poenina, le Valais à l'époque romaine. Musées Cantonaux du Valais, Sion, pp 29-34

Durali-Müller S (2005) Roman lead and copper mining in Germany: their origin and development through time, deduced from lead and copper isotope provenance studies. Ph.D. thesis, Frankfurt am Main

Eickenberg J, Köppel V, Labhart T, Signer P (1989) U-Pb, U-Xe and U-Kr systematics of a greenschist facies metamorphic uranium mineralization of the Siviez-Mischabel nappe (Valais, Switzerland). Bull Suisse Miner Petrogr 69:331-344

Elsig P (1993) Kopf oder Zahl? Die Geschichte des Geldwesens im Wallis. Musées Cantonaux du Valais, Sion

Fehlmann H (1919) Der Schweizerische Bergbau während des Weltkrieges. Volkwirtschafts Departement, Bergbau-Bureau, Kümmerly \& Frey, Bern, p 76

Frei-Stolba R (1999) Les sources écrites. In: Müller F, Kaenel G, Lüscher G (eds) La Suisse du Paléolithique à l'aube du Moyen Age: Age du Fer. SMP IV. Schweizerische Gesellschaft für Ur-und Frühgeschichte, Bâle, p 30

Gale NH, Stos-Gale ZA (1981) Cycladic lead and silver metallurgy. Annu Brit Sch Athens 76:169-224

Geiser A (2004) Les monnaies du Grand-Saint-Bernard antérieures au Principat et leurs circulations sur le territoire de la Suisse occidentale actuelle. Ph.D. thesis, University of Lausanne
Gottschalk R, Baumann A (2001) Material provenance of late Roman lead coffins in the Rheinland, Germany. Eur J Mineral 13:197205

Guénette-Beck B (2005) Minerais, métaux, isotopes: Recherches archéométriques sur les mines de plomb et d'argent en Valais, Suisse, Ph.D., University of Lausanne: 375

Guénette-Beck B (2007) Apport des analyses isotopiques de plomb à l'étude de la châsse. In: Schweizer F, Witschard D (eds) La châsse des enfants de saint Sigismond de l'Abbaye de SaintMaurice. Somogy, Paris, pp 187-192

Gueymard M (1814) Extrait d'une notice sur la géologie et la minéralogie du Simplon et sur les moyens d'utiliser dans les arts les substances minérales que ce département renferme. J Mines (Paris) 205:35

Haldimann MA (1998) Un baromètre révélateur de la société: le commerce. Vallis Poenina, le Valais à l'époque romaine. Musées Cantonaux du Valais, Sion, pp 93-98

Hunt Ortiz M (2003) Prehistoric mining and metallurgy in south west Iberian Peninsula. BAR International series 1188. Archaeopress, Oxford

Huttenlocher F (1934) Die Erzlagerstätten der Westalpen. Schweiz Mineral Petrogr Mitt 14:22-148

Köppel V (1997) Bleiisotope. In: Weber L (ed) Handbuch der Lagerstätten der Erze, Industrieminerale und Energierohstoffe Österreichs-Erläuterungen zur Metallogenetischen Karte von Österreich 1:500.000 unter Einbeziehung der Industrieminerale und Energierohstoffe. Archiv für Lagerstättenforschung der Geologischen Bundesanstalt, vol 19. Geologische Bundesanstalt, Wien, pp 485-495

Köppel V, Schroll E (1983) Bleiisotope und Remobilisation von Erzlagerstätten. Erdwissenschaftl. Kommissionen 6:39-51

Köppel V, Schroll E (1985) Herkunft des Pb der triassischen Pb-ZnVererzungen in den Ost- und Südalpen. Arch f Geol Lagerst Forsch Geol B-A 6:215-222

Krahn L, Baumann A (1996) Lead isotope systematics of epigenetic lead-zinc mineralization in the western part of the Rheinisches Schiefergebirge, Germany. Miner Depos 31:225-237

Kramers JD, Tolstikhin IN (1997) Two terrestrial lead isotope paradoxes, forward transport modelling, core formation and the history of the continental crust. Chem Geol 139:75-110

Kündig E, De Quervain F (1941) Fundstellen mineralischer Rohstoffe in der Schweiz. Kümmerly \& Frey, Bern

Le Guen M, Orgeval JJ, Lancelot J (1991) Lead isotope behaviour in a polyphased $\mathrm{Pb}-\mathrm{Zn}$ ore deposit: Les Malines (Cévennes, France). Miner Depos 26:180-188

Lippolt HJ, Schorn U, Pidgeon RT (1983) Genetic implications of new lead isotope measurements on Schwarzwald and Upper Triassic sediment galenas. Geologische Rundschau 72:77-104

Mange P (1998) Minéralisations $\mathrm{Pb}-\mathrm{Zn}-\mathrm{Ag}-(\mathrm{Ba})$ de Siviez (Pennique valaisan, Suisse). Diploma thesis, University of Geneva 97

Marcoux E (1986) Isotopes du plomb et paragenèses métalliques, traceurs de l'histoire des gîtes minéraux. Illustration des concepts de sources, d'héritage et de régionalisme dans les gîtes français, application en recherche minière. Clermont-Ferrand (Thèse d'état), Document du BRGM 117

Martin C (1987) L'atelier monétaire de Saint-Maurice-d'Agaune. Vallesia XLII:369-383

Niederschlag E, Pernicka E, Seifert T, Bartelheim M (2003) The determination of lead isotope ratios by multiple collector ICPMS: a case study of early bronze age artefacts and their possible relation with ore deposits of the Erzgebirge. Archaeometry 45:61-100

Payot C (2000) Les mines de Bagnes et les fonderies d'argent. In: Deslarzes-May S, Payot C, Deslarzes B (eds) 1150-2000: Bagnes imaginée, Bagnes vécue. Musée de Bagnes, Bagnes, pp 100-121 
Pernet L, Carlevaro E (2006) La necropoli di Giubiasco (TI), vol II. Swiss National Museum, Zurich

Rohl B (1996) Lead isotope data from the Isotrace Laboratory, Oxford: archaeometry data base 2, galena from Britain and Ireland. Archaeometry 38(1):165-180

Santos Zalduegui JF, García de Madinabeitia S, Gil Ibarguchi JI, Palero F (2004) A lead isotope database: the Los PedrochesAlcudia area (Spain): implications for archaeometallurgical connections across southwestern and southeastern Iberia. Archaeometry 46(4):625-634

Schweizer F, Witschard D (2007) La châsse des enfants de saint Sigismond de 1'Abbaye de Saint-Maurice. Somogy, Paris

Stalder HA, Wagner A, Graeser S, Stuker P, Offermann E, Meisser N (1998) Mineralienlexikon der Schweiz. Wepf, Basel, p 579

Stos ZA, Gale NH, Houghton J, Speakman R (1995) Lead isotope data from the Isotrace Laboratory, Oxford: archaeometry data base 1, ores from the western Mediterranean. Archaeometry 37(2):407-415

Stos ZA, Gale NH, Annetts N (1996) Lead isotope data from the Isotrace Laboratory, Oxford: archaeometry data base 3, ores from the Aegean, Part I. Archaeometry 38(2):381-390

Stos-Gale ZA, Gale NH, Annetts N, Todorov T, Lilov P, Raduncheva A, Panayotov I (1998) Lead isotope data from the Isotrace Laboratory, Oxford. Archaeometry data base 5, ores from Bulgaria. Archaeometry 40:217-326
Thurre D (1992) L'atelier d'orfèvrerie de l'Abbaye de Saint-Maurice, Sierre, p 321

Tincherini PR, Barbero P, Quadrati P, Domergue C, Long L (2001) Where do the lead ingots of the Saintes-Maries-de-la-Mer wreck come from? Archaeology compared with physics. Archaeometry 43:393-406

Tori L, Guénette-Beck B, Hubert V (2009) La necropoli di Giubiasco (TI), Vol IV. Swiss National Museum, Zurich (in press)

Villa IM (2009) Lead isotopic measurements in archaeological objects. Archaeol Anthropol Sci (current volume)

Vogt ML (2002) Etude minéralogique et géochimique du filon à $\mathrm{Pb}-\mathrm{Zn}-\mathrm{Cu}$ du Dorneloch (Steinbach, France). Master thesis, Lausanne

von Quadt A (1985) Geochronologische, geochemische und isotopengeochemische Untersuchungen an Gesteinen der HabachFormation, der Scheelitlagerstätte und des angrenzenden Altkristallins im Felbertal (Land Salzburg). Ph.D. thesis, ETH Zürich

Woodtli R, Jaffé F, von Raumer J (1987) Prospection minière en Valais: le projet Uromine. Matériaux pour la géologie de la Suisse, Série géotechnique, Commission Géotechnique Suisse. Livraison 72

Zingg M (1989) Die Siviez-Mischabel Decke: Entstehung und Entwicklung eines Altkristallins und seiner Vererzungen (Wallis, Schweiz). Ph.D. thesis, ETH Zurich 